\title{
Metformin reduces NAD(P)H oxidase activity in mouse cultured podocytes through purinergic dependent mechanism by increasing extracellular ATP concentration
}

\author{
Agnieszka Piwkowska1 ${ }^{凶}$, Dorota Rogacka ${ }^{1}$, Maciej Jankowski ${ }^{1,2}$ and Stefan Angielski ${ }^{1}$ \\ 1Mossakowski Medical Research Centre Polish Academy of Sciences, Laboratory of Molecular and Cellular Nephrology, Gdańsk, Poland; 2Medical \\ University of Gdańsk, Department of Therapy Monitoring and Pharmacogenetics, Poland
}

\begin{abstract}
Hyperglycemia affects the functioning numbers of podocytes and leads to a gradual decline of renal function. The normalization of glucose level is a principle therapeutic goal in diabetic patients and metformin is a popular hypoglycemic drug used in type 2 diabetes mellitus. Metformin activates AMP-activated kinase (AMPK) and decreases $N A D(P) H$ oxidase activity in podocytes leading to reduction of free radical generation. Similar effects are observed after activation of P2 receptors. Therefore, we investigated whether metformin increases extracellular ATP concentration and affects the activities of NAD(P) $\mathrm{H}$ oxidase and AMPK through $\mathrm{P} 2$ receptors. Experiments were performed on cultured mouse podocytes. NAD(P) $\mathrm{H}$ oxidase activity was measured by chemiluminescence and changes in AMPK activity were estimated by immunoblotting against AMPKa-Thr ${ }^{172}-\mathrm{P}$. Metformin increased extracellular ATP concentration by reduction of ectoATPase activity, decreased NAD(P)H oxidase activity and increased AMPK phosphorylation. A P2 receptor antagonist, suramin $(300 \mu \mathrm{M})$, prevented metformin action on $\mathrm{NAD}(\mathrm{P}) \mathrm{H}$ oxidase and AMPK phosphorylation. The data suggests a novel mechanism of metformin action, at least in podocytes. Metformin, which increases extracellular ATP concentration leads to activation of P2 receptors and consequent modulation of the podocytes' metabolism through AMPK and NAD(P)H oxidase which, in turn, may affect podocyte functioning.
\end{abstract}

Key words: AMP-activated kinase, free radicals, metformin, NAD(P)H oxidase, podocytes, purinoceptors

Received: 28 June, 2013; revised: 30 August, 2013; accepted: 02 September, 2013; available on-line: 30 December, 2013

\section{INTRODUCTION}

Podocytes are highly differentiated, insulin-dependent glomerular epithelial cells contributing to glomerular filtration barrier (Pavenstädt et al., 2003; Diez-Sampedro et al., 2011). Their dysfunction and injury in the course of hyperglycemia lead to changes in glomerular permeability and impairment of renal functions in patients with diabetes mellitus ( $\mathrm{Li}$ et al., 2007; Reddy et al., 2008). Therefore, a range of glucose-lowering agents with different properties are used to prevent the progression to end-stage renal disease in diabetes mellitus. Metformin (1,1-dimethylbiguanide) is the most widely prescribed drug to treat hyperglycemia in individuals with type 2 diabetes (Viollet et al., 2012). In the blood, metformin is not bound to plasma proteins but is eliminated into the urine unchanged through glomerular filtration and tubular secretion (Masuda et al., 2006; Graham et al., 2011). It is transported primarily by organic cation transporters (OCTs), particularly 1 and 2, and multidrug and toxin extrusion proteins (MATEs), namely MATE1, highly expressed in the kidney, and MATE2. Metformin inhibits gluconeogenesis in the liver and stimulates glucose uptake by muscle and fat tissue. The therapeutic action of metformin is mediated by its action on AMP-activated kinase (AMPK) which switches cells from anabolic to catabolic state and restoring energy balance (Zhou et al., 2001; Stephenne et al., 2011). Metformin significantly decreases the urine albumin excretion rate in patients with type 2 diabetes (Amador-Licona et al., 2000) and has beneficial effects in patients with renal function impairment (Ekström et al., 2012). Recent studies in a rat model of type 2 diabetes have provided evidence that metformin suppresses the diabetes-induced loss of podocytes through repression of oxidative injury (Kim et al., 2012). We have shown that metformin decreases NAD $(\mathrm{P}) \mathrm{H}$ oxidase activity leading to reduction of reactive oxide species generation and activates AMPK in cultured podocytes (Piwkowska et al., 2010). Similar effects regarding the activities of $\mathrm{NAD}(\mathrm{P}) \mathrm{H}$ and AMPK have been observed after short-term activation of P2 receptors in podocytes (Piwkowska et al., 2011). These receptors activated by extracellular nucleotides are part of the purinergic system and are classified into two groups: ATP-gated non-selective cation channels, $\mathrm{P} 2 \mathrm{X}_{1-7}$, and $\mathrm{G}$ protein-coupled metabotropic receptors, P2Y $\mathrm{Y}_{124611-14}$ (Abbracchio et al., 2006; Jarvis \& Khakh, 2009). The extracellular ATP concentration is determined by a balance between the capacity of the cells to ATP release and its hydrolysis. Molecular and pharmacological studies have shown that $\mathrm{P} 2 \mathrm{X}_{4,5,6,7}$ and $\mathrm{P}_{2} \mathrm{Y}_{1,2,4,6,1}$ receptors are expressed in podocytes and their activation modulates cell functioning, including glucose uptake (Fischer et al., 2001; Jankowski, 2008).

Thus, we checked the hypothesis that metformin induces the changes in AMPK and NAD(P)H oxidase activities through a mechanism involving $\mathrm{P} 2$ receptors. We provided evidence that metformin increases extracellular ATP concentration by inhibiting ecto-ATPase activity, thereby leading to activation of the P2 receptors.

e-mail: apiwkowska@imdik.pan.pl

Abbreviations: AMPK, AMP-activated kinase; MET, metformin 


\section{MATERIAL AND METHODS}

Materials. Cell culture reagents, metformin, suramin and ARL 67156 were from Sigma-Aldrich (St. Louis, $\mathrm{MO}$ ) and fetal bovine serum (FBS) was from Gibco, Invitrogen (Carlsbad, CA). Reagents for SDS-PAGE were purchased from MP Biochemicals, with the exception of the protein standard (Bio-Rad, Hertfordshire, UK) and protease inhibitor cocktail (Sigma-Aldrich). Primary rabbit polyclonal antibody to AMPK $\alpha$ and rabbit monoclonal antibody to $\mathrm{p}-\mathrm{AMPK} \alpha$ (Thr172) were from Cell Signaling Technology (Danvers, MA). Alkaline phosphatase-conjugated secondary goat anti-rabbit antibodies were from Santa Cruz Biotechnology. ATP Bioluminescence Assay Kit CLS II was from Roche Diagnostics (Mannheim, Germany). All other agents were purchased from POCh (Gliwice, Poland).

Cell culture. Mouse podocytes from a conditionally immortalized cell line were cultured as described previously (Piwkowska et al., 2011). Cells were grown in RPMI 1640 medium supplemented with 10\% FBS, penicillin $(100 \mathrm{U} / \mathrm{l})$, and streptomycin $(100 \mu \mathrm{g} / \mathrm{l})$ in a controlled $\left(5 \% \mathrm{CO}_{2}\right)$ humidified atmosphere. To propagate podocytes, the culture medium was supplemented with $10 \mathrm{U} / \mathrm{ml}$ mouse recombinant $\gamma$-interferon $(\gamma$ $\mathrm{INF}$ ) and the cells cultivated at $33^{\circ} \mathrm{C}$ to enhance the expression of the temperature-sensitive large $\mathrm{T}$ antigen (permissive conditions). To induce differentiation, podocytes were maintained at $37^{\circ} \mathrm{C}$ without $\gamma$-INF (nonpermissive conditions) for 1 week before starting the experiments.

Western blot analysis. Podocytes were treated with lysis buffer (1\% Nonidet P-40, $20 \mathrm{mM}$ Tris, $140 \mathrm{mM}$ $\mathrm{NaCl}, 2 \mathrm{mM}$ EDTA, $10 \%$ glycerol) in the presence of a protease inhibitor cocktail and homogenized at $4^{\circ} \mathrm{C}$ by scraping. The cell homogenates were centrifuged at $9500 \times \mathrm{g}$ for $20 \mathrm{~min}$ at $4^{\circ} \mathrm{C}$. Proteins $(20 \mu \mathrm{g})$ in the supernatants were separated on an SDS-polyacrylamide gel $(10 \%)$ and electrotransferred to a nitrocellulose mem- brane. The membrane was blocked for $1.5 \mathrm{~h}$ with Trisbuffered saline (TBS) $(20 \mathrm{mM}$ Tris $/ \mathrm{HCl}, 140 \mathrm{mM} \mathrm{NaCl}$, $0.01 \% \mathrm{NaN}_{3}$ ) containing 3\% non-fat dry milk, washed with TBS containing $0.1 \%$ Tween-20 and $0.1 \%$ bovine serum albumin (BSA), and incubated overnight at $4^{\circ} \mathrm{C}$ with primary antibody. Anti-AMPK $\alpha$ and anti-AMPK $\alpha$ phosphothreonine 172 antibodies were diluted 1:750 in TBS containing $0.05 \%$ Tween-20 and 1\% BSA. To detect primary antibodies bound to the immunoblot, the membrane was incubated for $2 \mathrm{~h}$ with alkaline phosphatase-labeled secondary antibodies. Protein bands were detected using the colorimetric 5-bromo-4-chloro-3-indolylphosphate/nitroblue tetrazolium system. The density of the bands was quantitated using the Quantity One program (Bio-Rad).

NAD $(\mathbf{P}) \mathbf{H}$ oxidase assay. $\mathrm{NAD}(\mathrm{P}) \mathrm{H}$ oxidase activity in podocytes was measured by the lucigenin-enhanced chemiluminescence method with modifications (Piwkowska et al., 2010). To measure superoxide anion generation, cell homogenates $(50 \mu \mathrm{g}$ protein) were added to PBS buffer containing $1 \mathrm{mM}$ EDTA and $5 \mu \mathrm{M}$ lucigenin. The assay was initiated by adding $100 \mu \mathrm{M}$ NADPH. Photon emission, in terms of relative light units, was measured every $30 \mathrm{~s}$ for $12 \mathrm{~min}$ in an FB12 luminometer (Berthold). There was no measurable activity in the absence of NADPH. The amounts of superoxide were calculated by integrating the area under the signal curve. These values were compared with a standard curve generated using xanthine/xanthine oxidase. Protein content was measured with the Lowry method.

Measurement of extracellular concentration and intracellular content of ATP. Podocytes were incubated for a short-time (15 $\mathrm{min})$ with various metformin concentrations in the range of $0.01-2 \mathrm{mM}$ for determination of extracellular ATP concentration or for a longtime $(120 \mathrm{~min})$ with $2 \mathrm{mM}$ metformin for determination of the intracellular pool of ATP. Some experiments were performed in the presence of ARL 67156, an inhibitor of ecto-ATPase (100 $\mu \mathrm{M}, 15$-min pre-incubation). Incu-

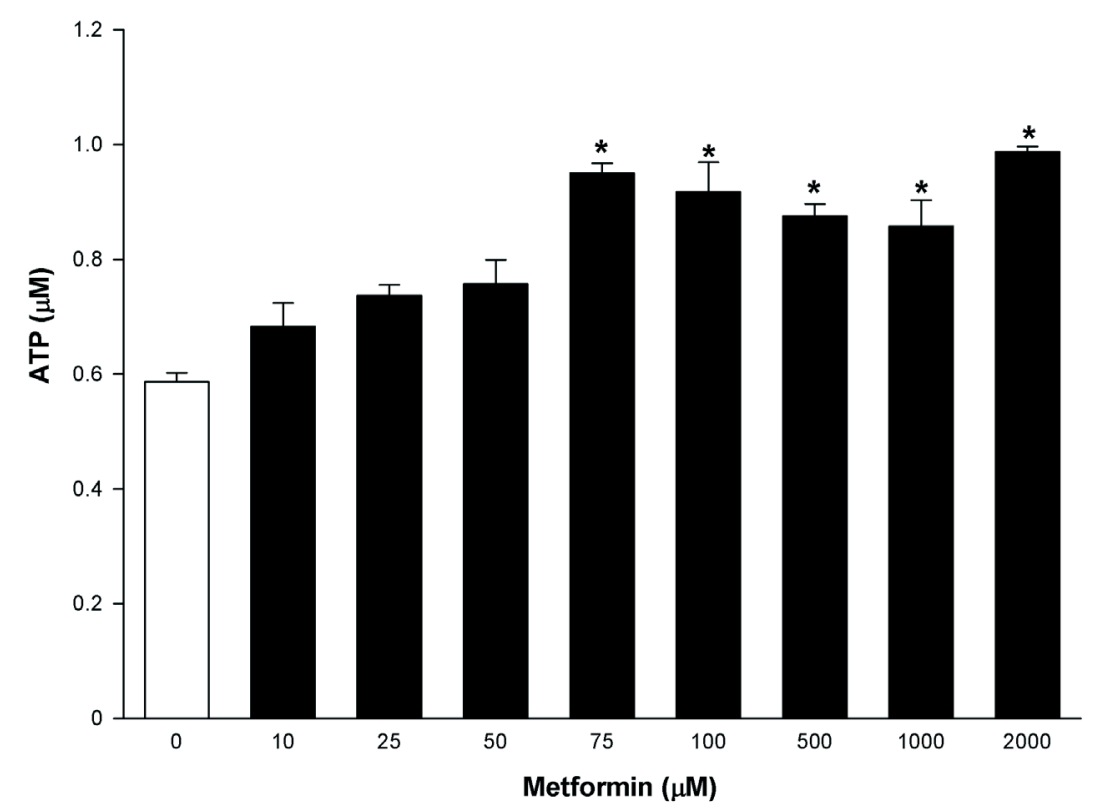

Figure 1. Time course of the effect of metformin on hydrolysis of extracellular ATP by cultured mouse podocytes.

Following 15-min preincubation without or with metformin in a range of concentrations $0.01-2 \mathrm{mM}$ cells were incubated for 3 min with $1 \mu \mathrm{M}$ ATP and supernatant was taken to measure ATP concentration using luciferin-luciferase method. Values are the mean \pm S.E.M. of 3-4 independent experiments. ${ }^{*} P<0.05$ with respect to absence of metformin. 
bation medium and homogenized cells were heated separately at $99^{\circ} \mathrm{C}$ for 2 minutes, centrifuged $\left(4^{\circ} \mathrm{C}, 800 \times \mathrm{g}\right.$, $10 \mathrm{~min}$ ) and immediately used for ATP determination. Concentration of ATP was measured using the luciferinluciferase method with an FB12 luminometer (Kimmich et al., 1975).

Determination of ecto-ATPase activity. Podocytes were incubated without or with metformin $(2 \mathrm{mM}, 15$ min) and then the rate of hydrolysis of exogenously added ATP $(1 \mu \mathrm{M})$ was determined by luminometric analysis of ATP concentration in supernatants collected at suitable time intervals.

Statistical analysis. Statistical analyses were performed by one-way ANOVA followed by the StudentNewman-Keuls test to determine significance. Values are reported as means \pm S.E.M. Significance was set at $P<0.05$.

\section{RESULTS}

\section{Effects of metformin on extra/intracellular pool of ATP}

Metformin significantly inhibited hydrolysis of exogenous $1 \mu \mathrm{M}$ ATP (Fig. 1); the effect was concentration dependent until a maximum was reach at 75 $\mu \mathrm{M}$ metformin $(0.95 \pm 0.02 \mu \mathrm{M}$ vs $0.52 \pm 0.01 \mu \mathrm{M})$ followed by a plateau up to $2 \mathrm{mM}$ metformin (Fig. 1). The magnitude of the inhibitory effect of metformin was similar to that of $100 \mu \mathrm{M}$ ARL 67156, a known inhibitor of ecto-ATPase. No additional effect of metformin was observed during co-incubation with ARL 67156 (Fig. 2A). Furthermore, as it is presented in Fig. $2 \mathrm{~B}$, the inhibitory effect of $2 \mathrm{mM}$ metformin was significant also at shorter time intervals. In contrast to its effect on extracellular ATP stability, metformin did not significantly affect the intracellular content of $\operatorname{ATP}(51.2 \pm 6.8$ vs $49.3 \pm 6.7 \mu \mathrm{mol} / \mathrm{mg}$ protein $)$.

\section{Effect of metformin on AMPK phosphorylation}

Next, we estimated the effect of metformin on AMPK activity (Fig. $3 \mathrm{~A}$ and B). Exposing the podocytes to $2 \mathrm{mM}$ metformin for 2 hours resulted in AMPK phosphorylation assessed as the densitometric ratio of its phosphorylated form to the total AMPK protein $(1.41 \pm 0.12$ vs. $1.06 \pm 0.06)$. Suramin, a non-selective P2 receptor antagonist, was used to explore the involvement of P2 receptors in the metformin-induced AMPK phosphorylation. Pre-incubating podocytes with suramin ( $300 \mu \mathrm{M}, 5 \mathrm{~min}$ ) abolished the effect of metformin on AMPK phosphorylation. These results suggest that the metformin-induced AMPK phosphorylation is mediated via $\mathrm{P} 2$ receptors.

\section{Effect of metformin on $\mathrm{NAD}(\mathrm{P}) \mathrm{H}$ oxidase activity}

As it is shown in Fig. 3C, metformin ( $2 \mathrm{mM}, 2 \mathrm{~h})$ significantly decreased by $32 \%$ the NAD(P)H oxidase activity $(1.76 \pm 0.03$ vs. $2.78 \pm 0.06 \mathrm{nmol} / \mathrm{min} / \mathrm{mg}$ protein, $P<0.05)$. Preincubation of the podocytes with suramin ( $300 \mu \mathrm{M}, 5 \mathrm{~min}$ ) abolished the effect of metformin on the NAD(P)H oxidase activity. These results suggest an involvement of $\mathrm{P} 2$ receptors in the metformin-mediated changes in rate of $\mathrm{O}_{2}^{-}$generation in cultured mouse podocytes.

\section{DISCUSSION}

In the present study we provide evidence for a novel mechanism of metformin action. Exposure of cultured podocytes to relatively low concentrations of metformin $(10-75 \mu \mathrm{M})$ affects purinergic signaling through inhibition of ecto-ATPase causing an increase of the extracellular ATP concentration and activation of P2 receptors with subsequent activation of AMPK and reduction of $\mathrm{NAD}(\mathrm{P}) \mathrm{H}$ oxidase activity. Thus, the biological effects of metformin may be modified by purinergic signaling,
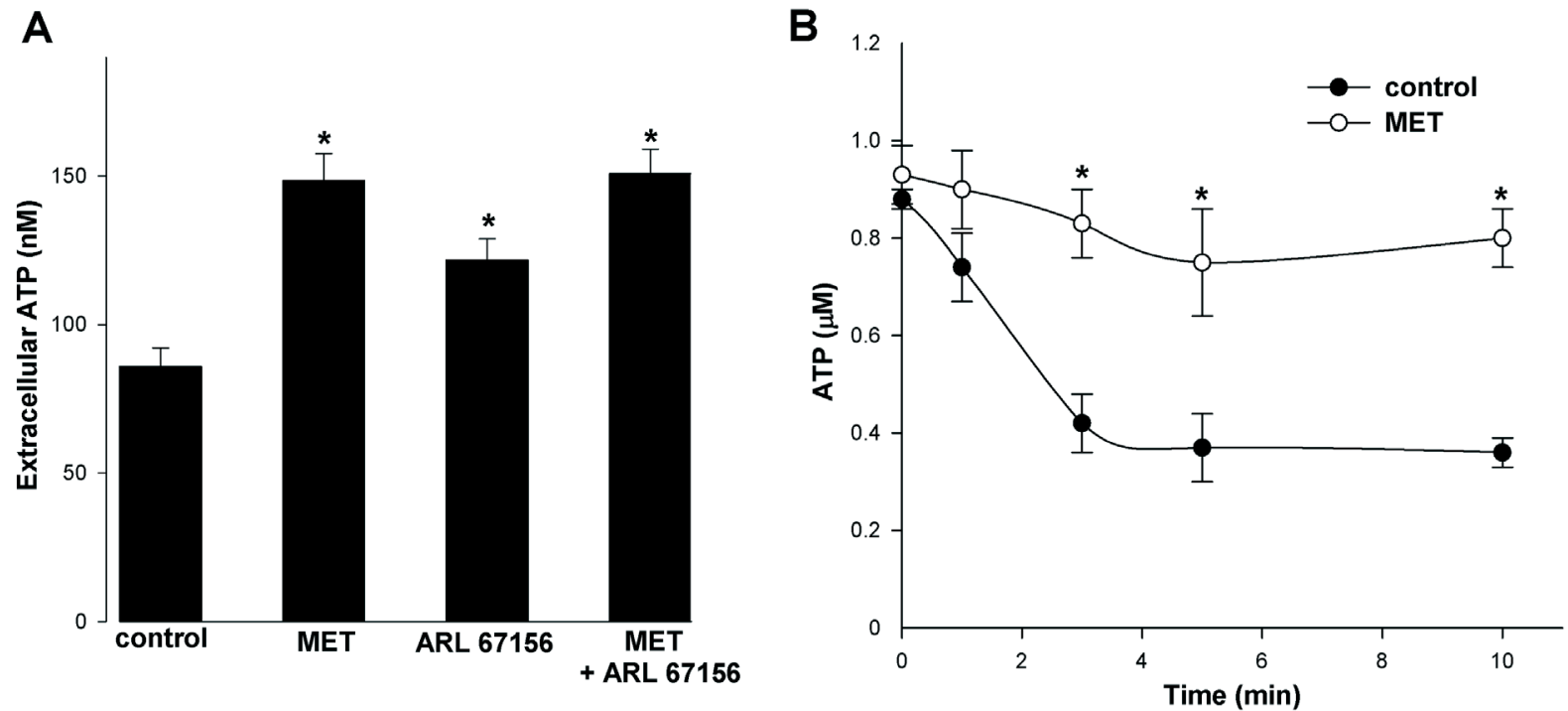

Figure 2. Effect of metformin on extracellular ATP hydrolysis by cultured mouse podocytes.

Following 15-min preincubation without or with $100 \mu \mathrm{M}$ ARL 67156 cells were incubated for 15 min with 2 mM metformin and then ATP concentration in incubation medium was measured $(\mathbf{A})$ or cells were incubated for 15 min with $2 \mathrm{M}$ metformin, then $1 \mu \mathrm{M}$ ATP was added to cells for indicated time and ATP concentration in incubation medium was measured (B). ATP concentration in incubation medium was measured using luciferin-luciferase method. Values are the mean \pm S.E. of 3-4 independent experiments. ${ }^{*} P<0.05$ with respect to appropriate control. 
A

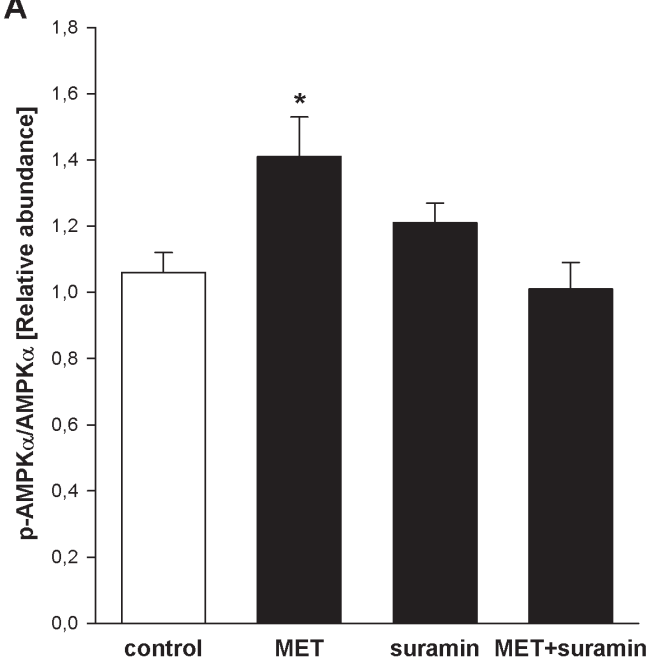

C

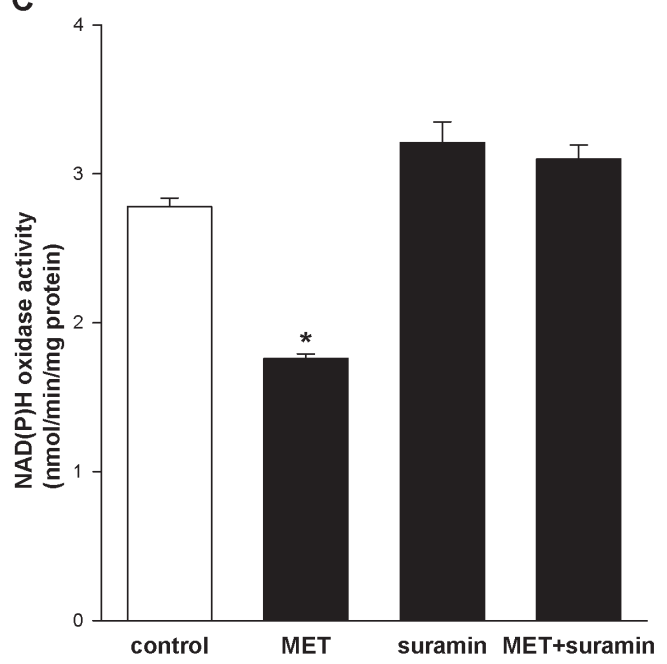

B

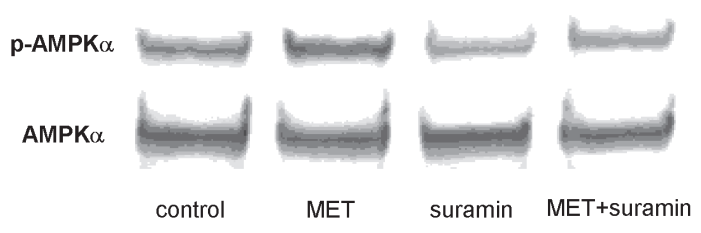

Figure 3. Effect of suramin on metformin-induced changes in AMPK phosphorylation in cultured mouse podocytes.

Following 5-min preincubation without or with $300 \mu \mathrm{M}$ suramin cells were incubated for 15 min with $2 \mathrm{mM}$ metformin. Cell were lysed and immunoblotted with anti-AMPK $\alpha\left(\right.$ Thr $\left.{ }^{172}-\mathrm{P}\right)$ and anti-AMPK $\alpha$ antibodies $(\mathbf{A}, \mathbf{B})$ or were harvested to measure NAD(P)H oxidase activity using the lucigenin enhanced method $(\mathbf{C})$. Values are the mean \pm SE of 3-4 independent experiments $(\mathbf{A}, \mathbf{C})$. ${ }^{*} P<0.05$ with respect to control. A. The relative abundance of optical density of the bands. B. Representative Western blot of podocytes stimulated with metformin in the presence or absence of suramin.

at least in cultured podocytes. This novel mechanism could hopefully constitute a new pharmacological target in patients with type 2 diabetes mellitus, especially those with diabetic nephropathy/podocytopathy.

The podocytes are insulin-dependent renal glomerular cells forming an outer layer of the glomerular filtration barrier. Their dysfunction, called podocytopathy, is observed in diabetes mellitus and leads to renal function impairment (Pavenstädt et al., 2003; Diez-Sampedro et al., 2011). The factors involved in the pathogenesis of diabetic podocytopathy are multifaceted. Among them reactive oxide species are important. They can induce actin filament polymerization leading to cytoskeletal dysfunction and consequent structural changes of podocytes affecting glomerular permeability. The main source of reactive oxide species in podocytes is the multi-subunit $\mathrm{NAD}(\mathrm{P}) \mathrm{H}$ oxidase generating the superoxide anion. All components of the NAD $(\mathrm{P}) \mathrm{H}$ oxidase complex, including p22phox, p47phox, and the NOX isoforms are expressed in podocytes (Eid et al., 2009). Additionally, diabetes mellitus is associated with disturbances in diverse extra/ intracellular metabolic signalling pathways, including the purinergic ones. The latter comprise extracellular hydrolases e.g., ecto-nucleotide pyrophosphatase/phosphodiesterases (E-EPPs) and enzyme synthesizing the nucleotides, as well as P2 receptors of two types: P2X and P2Y. Their activation results in a rise of the concentration of calcium ions in the cytoplasm, which triggers a variety of intracellular events depending on cell type. Moreover, activation of $\mathrm{P} 2 \mathrm{Y}$ receptors may also result in changes of intracellular AMP concentration (Abbracchio et al., 2006; Jarvis \& Khakh, 2009). Extracellular nucleotides modulate a number of intracellular signal transduction pathways (da Silva et al., 2006; Burnstock, 2007). It has been shown that activation of P2 receptors influences the activity of AMPK (da Silva et al., 2006). This enzyme, a major cellular energy sensor and a key regulator of metabolic homeostasis, is activated by $\mathrm{Ca}^{+2} /$ and AMP-dependent pathways. It is activated (phosphorylation of $\mathrm{Thr}^{172}$ on $\alpha$ subunit of the heterotrimeric complex) under conditions leading to a rise of the intracel-

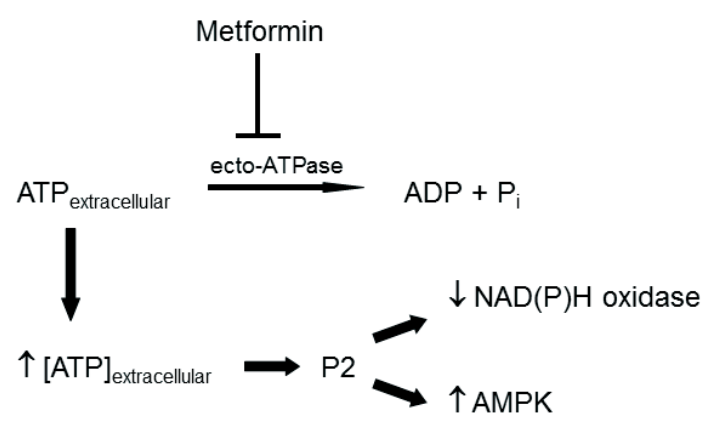

Figure 4. Proposed novel mechanism of metformin action. Metformin inhibits ecto-ATPase activity leading to an increased extracellular ATP concentration, subsequent activation of P2 receptors and eventual reduction of $\mathrm{NAD}(\mathrm{P}) \mathrm{H}$ oxidase activity and enhancement of AMPK activity. 
lular AMP/ATP ratio (e.g., glucose deprivation, hypoxia) or upon parcrine/autocrine stimulation (Zhang \& Zhou, 2009; Foretz \& Viollet, 2011). Recently, we have shown that a diabetic milieu affects purinergic modulation of glucose transport into cultured podocytes (Karczewska et al., 2007). Taken together, an increased glucose concentration leads to many cellular disturbances and therefore, the main goal of treatment of diabetic patients is normalization of glycemia. Metformin is an insulin-sensitizing biguanide with anti-hyperglycemic properties that is widely used to treat patients with type 2 diabetes mellitus (Viollet et al., 2012). The beneficial effects of metformin are well established and have also been demonstrated in patients with renal impairments in a population-based observational study (Ekström et al., 2012). Despite the established place of metformin in pharmacotherapy of hyperglycemia, its mechanism of action is not fully understood. There is evidence that metformin affects the rate of glucose metabolism through reducing the intracellular energy charge or/and by AMPK activation (Zhou et al., 2001). Our recent studies have shown that extracellular ATP through P2 receptors plays a role in restoring energy homeostasis after oxidative stress in podocytes (Piwkowska et al., 2011). ATP stimulates AMPactivated protein kinase via $\mathrm{Ca}^{+2} /$ calmodulin-dependent kinase kinase- $\beta$ and LKB1-STRAD-M025 complex, and in turn decreases $\mathrm{NAD}(\mathrm{P}) \mathrm{H}$ oxidase activity, the main source of reactive oxide species in podocytes. Now, we have shown that metformin increases extracellular ATP concentration. Two types of experiments suggest that metformin does it by inhibiting the extracellular hydrolysis of ATP. First, ARL 67156, a specific inhibitor of ecto-ATPase did not affect the metformin action, suggesting that these two agents affect extracellular ATP level by the same mechanism. Second, metformin was shown directly to significantly reduce the hydrolysis rate of extracellular ATP. Importantly, extracellular ATP concentration affects intracellular signaling and this action is mediated through P2 receptors. In podocytes, where ENPP1 is abundantly expressed metformin, even at a low concentration, would prolong the effect of endogenously released ATP on P2 receptors. Using suramin, a specific but non-selective antagonist of P2 receptors, we have shown that effect of metformin is indeed dependent on P2 receptors. However, further molecular studies using siRNA should be performed to identify the purinoceptors involved in metformin action on podocytes.

Our present results do not exclude the participation of a product of ATP hydrolysis (i. e., adenosine) in metformin action since we have previously shown that adenosine-induced AMPK phosphorylation also depends on the adenosine uptake via nucleoside transporters (Karczewska et al., 2007; Piwkowska et al., 2011).

To our knowledge this is the first report describing an involvement of purinoceptors in metformin action. The involvement of purinergic signaling has been investigated for nebivolol and carvedilol, third-generation $\beta$-adrenoreceptor antagonists in glomeruli. We have provided evidence that the vasodilator effect of nebivolol and carvedilol in renal glomerular microvasculature is associated with the activation of ATP efflux with consequent stimulation of P2Y-purinoceptor-mediated liberation of NO from glomerular microvascular endothelial cells (Kalinowski et al., 2003). Moreover, these drugs have beneficial effects on urinary albumin extraction both in experimental models and in patients with type 2 diabetes (Bakris et al., 2005; Whaley-Connell et al., 2009).

Based on our present results we propose a novel mechanism of metformin action. It inhibits ecto-ATPase activity leading to an increased extracellular ATP concentration, subsequent activation of $\mathrm{P} 2$ receptors and eventual reduction of $\mathrm{NAD}(\mathrm{P}) \mathrm{H}$ oxidase activity and enhancement of AMPK activity. Both these changes may have beneficial effects for podocytes during metformin treatment in diabetic patients. We suggest that modulation of purinergic signaling may be a novel pharmacological target during metformin treatment in patients with diabetes type 2 .

\section{Acknowledgements}

This work was supported by grants from the $\mathrm{Na}$ tional Science Centre (grant No. N 2012/05/B/ NZ4/02587) and the Foundation for Polish Science (POMOST/2011-4/6) and by the statutory grant to the Mossakowski Medical Research.

\section{REFERENCES}

Abbracchio MP, Burnstock G, Boeynaems JM, Barnard EA, Boyer JL, Kennedy C, Knight GE, Fumagalli M, Gachet C, Jackobsen KA, Weisman GA (2006) International Union of Pharmacology LVIII: update on the P2Y G protein-coupled nucleotide receptors: from molecular mechanism and pathophysiology to therapy. Pharmacol Rev 58: $281-341$

Amador-Licona N, Guízar-Mendoza J, Vargas E, Sánchez-Camargo G, Zamora-Mata L (2000) The short-term effect of a switch from glibenclamide to metformin on blood pressure and microalbuminuria in patients with type 2 diabetes mellitus Arch Med Res 31: 571-575.

Bakris GL, Fonseca V, Katholi RE, McGill JB, Messerli F, Phillips RA, Raskin P, Wright JT, Waterhouse B, Lukas MA, Anderson KM, Bell DS, GEMINI Investigators (2005) Differential effects of betablockers on albuminuria in patients with type 2 diabetes. Hypertension 46: 1309-1315.

Burnstock G (2007) Physiology and pathophysiology of purinergic neurotransmission. Physiol Rev 87: 659-797.

Diez-Sampedro A, Lenz O, Fornoni A (2011) Podocytopathy in diabetes: a metabolic and endocrine disorder. Am J Kidney Dis 58: 637-646.

Eid AA, Gorin Y, Fagg BM, Maalouf R, Barnes JL, Block K, Abboud HE (2009) Mechanisms of podocyte injury in diabetes: role of cytochrome P450 and NADPH oxidases. Diabetes 58: 1201-1211.

Ekström N, Schiöler L, Svensson AM, Eeg-Olofsson K, Jonasson MJ, Zethelius B, Cederholm J, Eliasson B, Gudbjörnsdottir S (2012) Effectiveness and safety of metformin in 51675 patients with type 2 diabetes and different levels of renal function: a cohort study from the Swedish National Diabetes Register. BMJ Open 2; doi: e001076.

Fischer KG, Saueressig U, Jacobshagen C, Wichelmann A, Pavenstädt H (2001) Extracellular nucleotides regulate cellular functions of podocytes in culture. Am J Physiol 281: F1075-F1081.

Foretz M, Viollet B (2011) Regulation of hepatic metabolism by AMPK. J Hepatol 54: 827-829.

Graham GG, Punt J, Arora M, Day RO, Doogue MP, Duong JK, Furlong TJ, Greenfield JR, Greenup LC, Kirkpatrick CM, Ray JE, Timmins P, Williams KM (2011) Clinical pharmacokinetics of metformin. Clin Pharmacokinet 50: 81-98.

Jankowski M (2008) Purinergic regulation of glomerular microvasculature and tubular function, J Physiol Pharmacol 59 (Suppl 9): 121-135.

Jarvis MF, Khakh BS (2009) ATP-gated P2X cation-channels. Neuropbarmacology 56: 208-215.

Kalinowski L, Dobrucki LW, Szczepanska-Konkel M, Jankowski M, Martyniec L, Angielski S, Malinski T (2003) Third-generation betablockers stimulate nitric oxide release from endothelial cells through ATP efflux: a novel mechanism for antihypertensive action. Circulation 107: 2747-2752.

Karczewska J, Martyniec M, Dzierzko G, Stepiński J, Angielski S (2007) The relationship between constitutive ATP release and its extracellular metabolism in isolated rat kidney glomeruli. J Physiol Pharmacol 58: 321-333.

Karczewska J, Piwkowska A, Rogacka D, Stępiński J, Angielski S, Jankowski M (2011) Purinergic modulation of glucose uptake into cultured rat podocytes: effect of diabetic milieu. Biochem Biophys Res Commun 404: 723-727.

Kim J, Shon E, Kim CS, Kim JS (2012) Renal podocyte injury in a rat model of type 2 diabetes is prevented by metformin. Exp Diabetes Res 2012: 210821.

Kimmich GA, Randles J, Brand JA (1975) Assay of picomole amounts of ATP, ADP, and AMP using the luciferase enzyme. Anal Biochem 69: 187-206. 
Li JJ, Kwak SJ, Jung DS, Kim JJ, Yoo TH, Ryu DR, Han SH, Choi HY, Lee JE, Moon SJ, Kim DK, Han DS, Kang SW (2007) Podocyte biology in diabetic nephropathy, Kidney Int 106: S36-S42.

Masuda S, Terada T, Yonezawa A, Tanihara Y, Kishimoto K, Katsura T, Ogawa O, Inui K (2006) Identification and functional characterization of a new human kidney-specific $\mathrm{H}+$ /organic cation antiporter, kidney-specific multidrug and toxin extrusion 2. I Am Soc Nephrol 17: 2127-2135.

Pavenstädt H, Kriz W, Kretzler M (2003) Cell biology of the glomerular podocytes. Physiol Rev 83: 253-307.

Piwkowska A, Rogacka D, Jankowski M, Dominiczak MH, Stepiński JK, Angielski S (2010) Metformin induces suppression of NAD(P) $\mathrm{H}$ oxidase activity in podocytes. Biochem Biophys Res Commun 393: 268-273.

Piwkowska A, Rogacka D, Jankowski M, Angielski S (2011) Extracellular ATP through P2 receptors activates AMP-activated protein kinase and suppresses superoxide generation in cultured mouse podocytes. Exp Cell Res 317: 1904-1913.

Reddy GR, Kotlyarevska K, Ransom RF, Menon RK (2008) The podocyte and diabetes mellitus: is the podocyte the key to the origins of diabetic nephropathy? Curr Opin Nephrol Hypertens 17: 32-36. da Silva CG, Jarzyna R, Specht A, Kaczmarek E (2006) Extracellular nucleotides and adenosine independently activate AMP-activated protein kinase in endothelial cells: involvement of P2 receptors and adenosine transporters. Circ Res 98: 39-47.

Stephenne X, Foretz M, Taleux N, van der Zon GC, Sokal E, Hue L, Viollet B, Guigas B (2011) Metformin activates AMP-activated protein kinase in primary human hepatocytes by decreasing cellular energy status. Diabetologia 54: 3101-3110.

Viollet B, Guigas B, Sanz Garcia N, Leclerc J, Foretz M, Andreelli F (2012) Cellular and molecular mechanisms of metformin: an overview, Clin. Sci. (Lond) 122: 253-270.

Whaley-Connell A, Habibi J, Johnson M, Tilmon R, Rehmer N, Rehmer J, Wiedmeyer C, Ferrario CM, Sowers JR (2009) Nebivolol reduces proteinuria and renal NADPH oxidase-generated reactive oxygen species in the transgenic Ren2 rat, Am J Nephrol 30: 354-360.

Zhang BB, Zhou G, Li C (2009) AMPK: an emerging drug target for diabetes and the metabolic syndrome, Cell Metab 9: 407-416.

Zhou G, Myers R, Li Y, Chen Y, Shen X, Fenyk-Melody J, Wu M, Ventre J, Doebber T, Fujii N, Musi N, Hirshman MF, Goodyear LJ, Moller DE (2001) Role of AMP-activated protein kinase in mechanism of metformin action, J Clin Invest 108: 1167-1174. 